\title{
Unesco and population genetics
}

SIR - We are members of the United Nations Educational, Scientific and Cultural Organization (Unesco) International Bioethics Committee Subcommittee on Population Genetics but are writing in our personal capacity in response to a recent leading article and News article (Nature 377, 372-373; 1995). In some respects your articles may have misrepresented our final report, which was revised in response to the many constructive comments that we have received from population geneticists and representatives of indigenous groups. A copy can be downloaded from the Internet at: http://www.biol.tsukuba.ac.jp/ macer /index.html

The subject of the report is population genetics, of which the Human Genome Diversity Project (HGDP) is only one example, albeit the grandest in ambition and design. The report does not "strongly criticize the HGDP", as implied by Declan Butler in your News pages. What we did criticize was the planners' failure to anticipate the reactions of some groups of indigenous peoples to the HGDP, as well as the delay between the planning of the project and the release of detailed measures to explain how "informed" consent would be obtained. However, obtaining informed consent is an ethical problem for many population research projects. The latest measures produced by the HGDP planners contain some of the most ethically sophisticated and detailed procedures for obtaining informed consent from individuals and groups in population genetics research.

Many of the other issues raised in the report apply to the whole of population genetics research. One is commercialization and use of the results of the collected DNA and cells. This controversial issue is discussed in our report, to the extent that it should be addressed by those involved in the collecting of samples and be part of the consent and cooperation agreements. The resolution of biotechnology patents and "genetic prospecting" was not a subject for our subcommittee to resolve, but we urge the clarification of this issue by a global body.

One issue dismissed by the leading article in Nature is that of eugenics and racism. Although it is probable that little population genetic diversity will be found that is unique to one particular group, there is a logical possibility that there may be distinct genetic features that make one genetic group distinct from others.

While eugenics (cf. Galton) was founded on racism, eugenics today does not have to be linked with racism. Those who continue to link their eugenics with racism will not be dissuaded by scientific evidence, since racism is an attitude of mind, or prejudice. People who tenaciously hold to such prejudices are usually not susceptible to the voice of pure reason and may even misappropriate scientific data to "prove" the truth of their own prejudices.

The fact that our report did not endorse any particular population genetics project is not a criticism of the HGDP. It rather is our personal view that the role given to us by Unesco could better be served, as could science, by the establishment of a separate ethical committee available to all population genetics researchers. Rather than being exclusively linked with one particular project and focusing attention solely on it, we want a wider selection of scientists to feel able to seek an international ethical committee, and we invite scientists to contact us.

\section{Darryl Macer}

Institute of Biological Sciences,

University of Tsukuba,

Tsukuba Science City,

Ibaraki 305, Japan

John Fleming

Southern Cross Bioethics Institute,

PO Box 206, Plympton,

South Australia 5038, Australia

Genoveva Keyeux

Instituto de Genetica Humana,

Pontificia Universidad Javieriana,

Carrera 7a. No 40-62, Apartade Aereo,

56710 Santafe de Bogota, DC, Columbia

Bartha Maria Knoppers

Faculty of Law,

Université de Montreal,

CP 6128, Montreal,

Quebec H3C 3J7, Canada

SIR - Your leading article "More focused agenda for Unesco" (Nature 378, 423-424; 1995) made two references to the International Council of Scientific Unions (ICSU) that merit correction. First, you state that "Unesco has been the chief source of support for ICSU". Although our links with Unesco have been very strong since that organization's foundation 50 years ago, Unesco's yearly financial contribution to ICSU now represents a little over 10 per cent of our income, and this is used solely to support the scientific activities of our members. Second, you say that "Unesco was one of the prime movers in launching the International Geophysical Year". In fact ICSU was the prime mover and sole sponsor of the International Geophysical Year which was a turning point in moving towards global science.

Unesco is, however, the sole intergovernmental organization devoted specifically to promoting science and technology, and it is a strong partner to the nongovernmental ICSU in a variety of scientific programmes in which both North and South participate. While the United Kingdom and the United States are full and active members of ICSU, their joining
Unesco would bring a great deal to that organization as well as to international science in general.

\section{Julia Marton-Lefèvre}

(Executive Director)

International Council

of Scientific Unions,

$51 \mathrm{Bd}$ de Montmorency,

Paris 75016, France

\section{ORI defended}

SIR - Mr Burton Appleton (Nature 378, $432 ; 1995)$ seems to have read only selected parts of the report of the ORI/AAAS Conference on Plagiarism and Theft of Ideas, the focus of his letter. He suggests there was "tampering" with the meeting transcript, but in the "Editor's Note" on the second page of the report, I clearly stated on behalf of the Office of Research Integrity (ORI): "As an organizer of this Conference and editor of this summary report, I edited the talks and discussion for brevity and consistency, as well as to remove some comments that were irrelevant to the conference topic... or were relevant to ongoing, non-public investigations of scientific misconduct" [emphasis added], such as the active case he cites.

Appleton also claims that comment from him in which he "took ORI to task for notifying the public only through announcements in the Federal Register", had been "struck from the record". I did so because his statement was inaccurate, given the response by the director of ORI, Dr Lyle Bivens, to the first comments. As Bivens stated: "ORI policy now is that when a case is closed and there is a misconduct finding, we will publicize that through a notice in the Federal Register and in the NIH Guide to Grants and Contracts.... The first time we published our ORI Newsletter that had the names of individuals found to have committed scientific misconduct in it [was in 1993]... The NIH Guide goes to some 34,000 addresses, and that is a very wide distribution in the scientific and academic community. The ORI Newsletter of course, goes to over 3,000 institutions that file assurances with our office, as well as to a substantial number of other people on the list. I think we give it very broad publicity." The information in these three ORI notices and other publications is often picked up by the press as well. There is no "burying" of ORI's findings as Appleton implies; ORI makes its findings very public.

ORI scientists are committed to upholding the principles of scientific integrity and to supporting open discussion of these issues, as we did when we sponsored this public conference on plagiarism.

\section{Alan R. Price}

Division of Research Investigations,

Office of Research Integrity,

5515 Security Lane, Suite 700,

Rockville, Maryland 20852,USA 